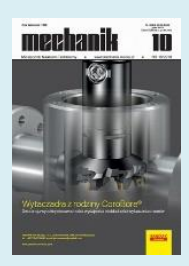

Authors: Jan Burek, Marcin Sałata, Anna Bazan

Title of article: „Wpływ parametrów technologicznych na jakość powierzchni w procesie jednoprzejściowego szlifowania rowków wiórowych frezów pełnowęglikowych" ("Influence of grinding parameters, on the surface quality in the process of single-pass grinding of flute in solid carbide end mill")

Mechanik, Vol. 91, No. 10 (2018): pages 808-810

DOI: https://doi.org/10.17814/mechanik.2018.10.135

\title{
Influence of grinding parameters on the surface quality in the process of single-pass grinding of flute in solid carbide end mill
}

\author{
Wpływ parametrów technologicznych na jakość powierzchni \\ w procesie jednoprzejściowego szlifowania \\ rowków wiórowych frezów pełnowęglikowych
}

\section{JAN BUREK \\ MARCIN SAŁATA \\ ANNA BAZAN *}

The paper presents analysis of influence cutting speed $v_{s}$ and feed rate $v_{f}$ of single-pas grinding process of flute in solid carbide end mill using diamond grinding wheel with metal bond on the geometrical structure and cutting force $F_{\mathrm{n}}$.

KEYWORDS: wheel diamond, metal bond, flute, carbide end mill

In the production of monolithic tools, the basic operation is grinding of chip flutes - this process takes about $70 \%$ of production time [2-4]. The classic grinding process is based on multi-pass shaping of the flute. Performing roughing and finishing machining involves making from several to several passes of the grinding wheel, which considerably extends the grinding time.

A new method, currently being investigated, is one-pass grinding. Its main advantage is the clear reduction of grinding time $[1,7,8]$. In this process, despite the significant increase in the removal efficiency of sanding, the desired surface quality is obtained by appropriate selection of technological parameters [5, 6].

In this context, research has been undertaken to determine the effect of grinding speed $v_{s}$ feed speed $v_{f}$ on the geometric structure of the surface and the normal component of the grinding force. The process of single-pass grinding of flute in a slot drill, was analyzed.

\section{Experimental research}

The basis of the test bench for grinding one-sided chip flutes in solid carbide milling cutters was the five-axis FORTIS grinding center from ISOG (fig. 1). The measurements of the topography of the flute surface were recorded using the Alicona Infinite Focus microscope. The sample was scanned at a $500 \mathrm{~nm}$ vertical resolution and a $2.50 \mu \mathrm{m}$ horizontal resolution using a $10 \times$ magnification lens.

\footnotetext{
* Dr hab. inż. Jan Burek, prof. PRz (jburek@prz.edu.pl); mgr inż. Marcin Sałata (msalata@prz.edu.pl); mgr inż. Anna Bazan (abazan@ prz.edu.pl) - Katedra Technik Wytwarzania i Automatyzacji, Wydział Budowy Maszyn i Lotnictwa Politechniki Rzeszowskiej
}

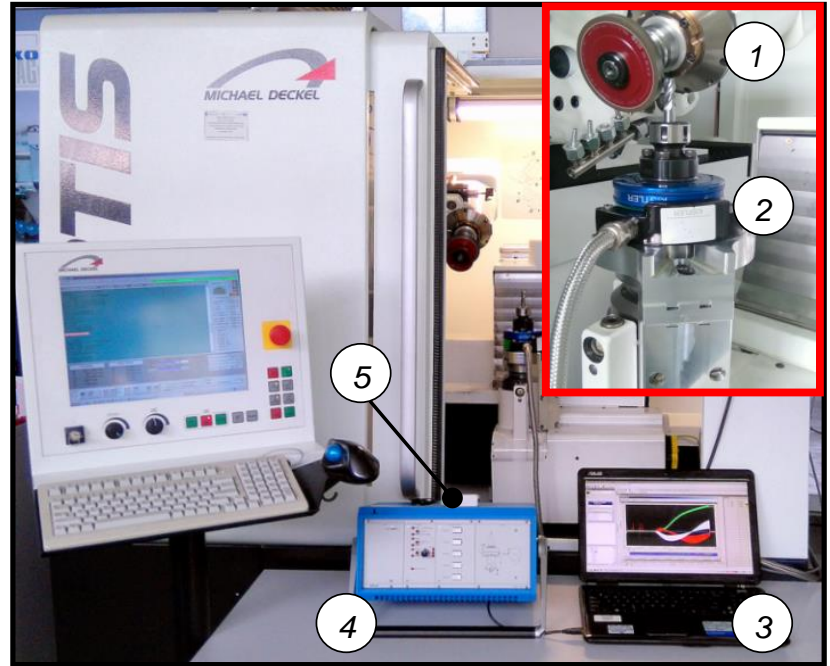

Fig. 1. Stand for testing the flute grinding process: 1 - grinding spindle, 2 - Kistler force meter, 3 - computer, 4 -5223B1 signal converter, $5-\mathrm{A} / \mathrm{C}$ converter 6009

The waviness profile was filtered by a filter $\lambda_{c}=0.27 \mathrm{~mm}$ In the obtained area of $1.4 \mathrm{~mm} \times 1.1 \mathrm{~mm}$, the surface roughness parameter Sa was recorded.

For the grinding process a grinding wheel with the designation 1A1 D100 U10 X10 H20 Y0,2 MDX-587 ES D64 C115 was used. It is a diamond grinding wheel type $1 \mathrm{~A} 1$ with a rectangular cross-section with a metal bond, $100 \mathrm{~mm}$ in diameter and $10 \mathrm{~mm}$ wide, with an average diameter of $64 \mu \mathrm{m}$ diamond grain and its $C 115$ concentration, which is $31.25 \%$ of the diamond volume in the entire layer abrasive.

A carbide type K20F was grinded, whose material properties are shown in the table I.

Variable parameters were the speed of grinding $v_{\mathrm{s}}$ and the feedrate $v_{f}$ (fig. 2).

TABLE I. Properties of sintered carbide

\begin{tabular}{|c|c|c|c|c|c|}
\hline $\begin{array}{c}\text { Co, } \\
\%\end{array}$ & $\begin{array}{c}\text { WC, } \\
\%\end{array}$ & $\begin{array}{c}\text { Hardness } \\
\text { HV30 }\end{array}$ & $\begin{array}{c}\text { Density, } \\
\mathrm{g}^{/ \mathrm{cm}^{3}}\end{array}$ & $\begin{array}{c}\text { Grain } \\
\text { size, } \\
\mu \mathrm{m}\end{array}$ & $\begin{array}{c}\text { Bending } \\
\text { strength, } \\
\mathrm{MPa}\end{array}$ \\
\hline 8 & 92 & 1700 & 14.6 & 0.7 & 3200 \\
\hline
\end{tabular}




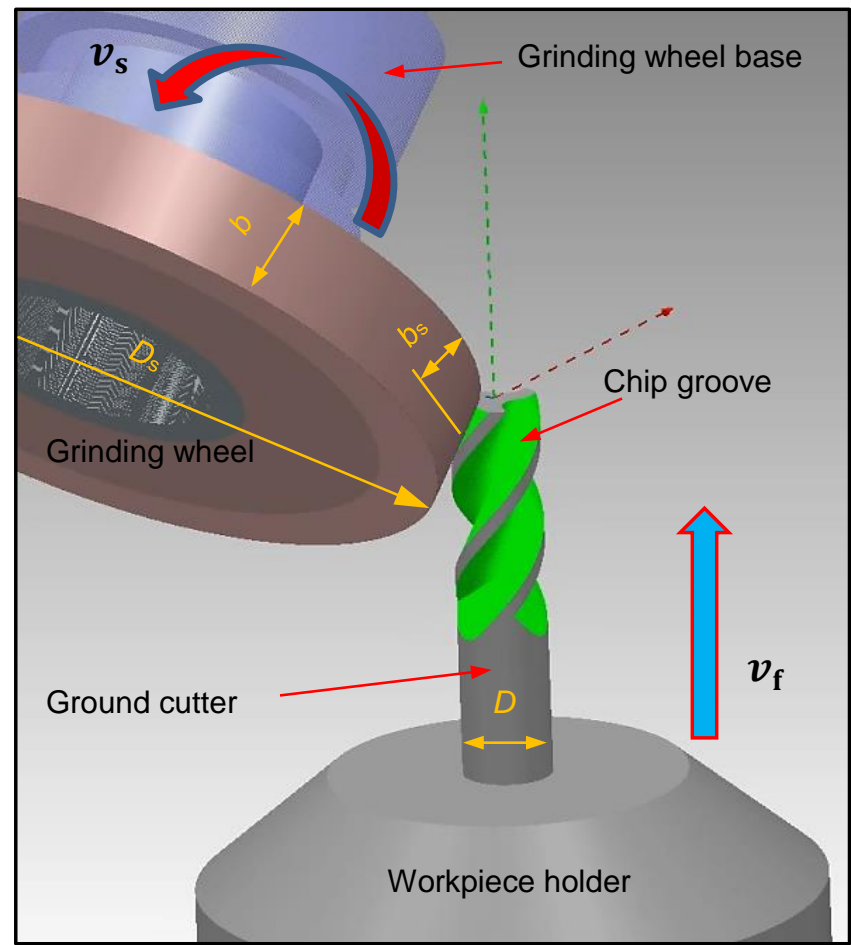

Fig. 2. Kinematics of five-axis, one-pass flute grinding: $v_{\mathrm{s}}-$ grinding speed, $v_{f}-$ feed speed, $D_{\mathrm{s}}-$ grinding wheel diameter, $D$ - workpiece diameter, $b-$ width of the grinding wheel, $b_{s}=a_{p}$ - active grinding wheel width

The constant parameters of the co-rotational grinding process were respectively:

- width $a_{\mathrm{e}}=3.5 \mathrm{~mm}$,

- depth $a_{p}=4.7 \mathrm{~mm}$,

- diameter of blank $D=10 \mathrm{~mm}$,

- number of teeth $z=4$,

- grinding length $L=25 \mathrm{~mm}$,

- cross-sectional area of the cutting layer $A=12.24 \mathrm{~mm}^{2}$.

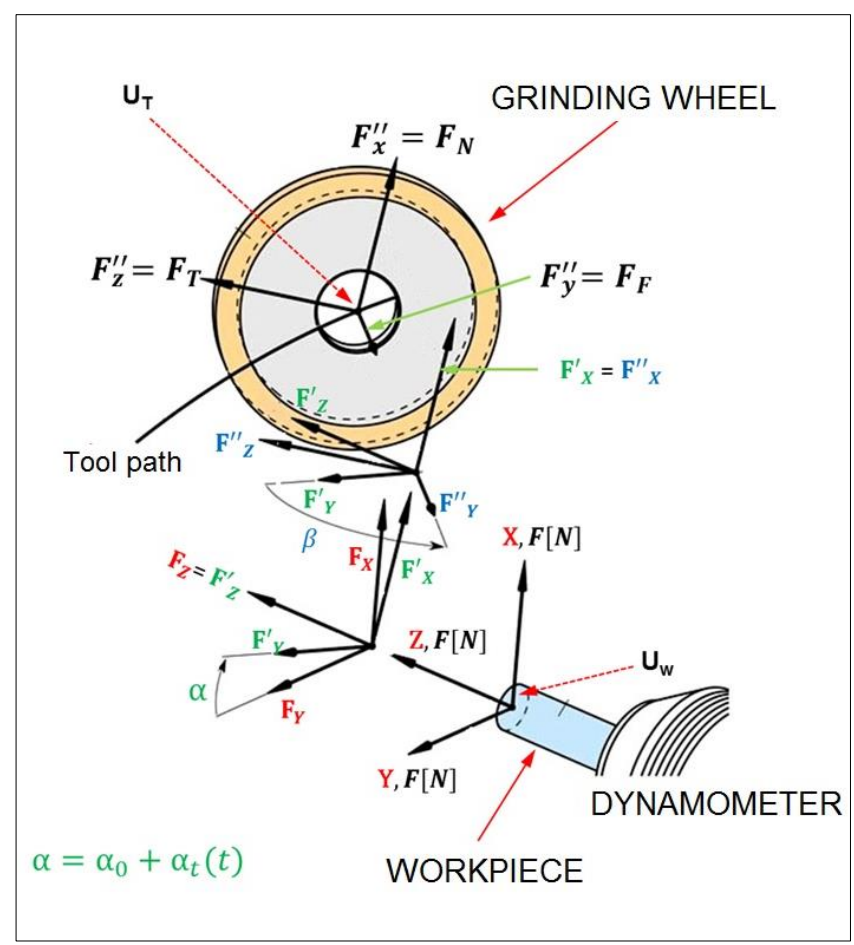

Fig. 3. Transformation of the sanding force component system: $X, Y, Z$ - dynamometer system; $X^{\prime}, Y^{\prime}, Z^{\prime}$ - dynamometer system taking into account its rotation by angle $\alpha ; X^{\prime \prime}, Y^{\prime \prime}, Z^{\prime \prime}-$ dynamometer system taking into account its rotation by $\beta$ angle; $F_{\mathrm{x}}, F_{\mathrm{y}}, F_{\mathrm{z}}$ - components of grinding forces in the direction of the $X$ $Y, Z$ axes; $\alpha-$ angle of the force meter's rotation; $\beta$ - torsion angle of the grinding wheel headstock
Measurement of the cutting force components was carried out using Kistler rotary milling force type 9123. In order to measure the components of clamping forces, a fixed reference point in the machine's working space must be determined - it may be a UT abrasive system. It results from the fact that the components of grinding forces are registered by a dynamometer mounted directly in the $U_{w}$ workpiece system. In order to better analyze the components of the grinding force of the spiral flutes, the system of force components was translated (fig. 3).

The elements of each vector $u$ related to the workpiece coordinate system $U_{w}$ can be transformed to the $U_{T}$ coordinate system by multiplying the matrix. The transformation matrix $T$ depends on the current position of the grinding wheel, which is determined by the tool path and described by three transcription parameters $X, Y, Z$ and two angular parameters $\alpha, \beta[1-3]$ :

$$
U_{\mathrm{T}}=U_{\mathrm{W}} \cdot T_{T \rightarrow W}^{\Delta}
$$

The first stage of translation takes into account the rotation of the dynamometer by the angle $\alpha$, which is variable at time $t$, because the grinding process of the flute causes continuous rotation of the dynamometer. This rotation is carried out in the range from 0 to $360^{\circ}$, which results in changes in the quarters of the system in which the system is translated. The second stage of the system's translation takes into account the change in the value of the angle of the wheel $\beta$ in the machine's spatial layout. The value of the angle $\beta$ depends on the value of the angle of the spiral of the flute and the type of grinding wheel used in the process.

\section{Test results}

According to the assumed research parameters, performance indicators were calculated:

- grinding efficiency: $Q_{w}=A \cdot v_{\mathrm{f}}\left[\mathrm{mm}^{3} / \mathrm{min}\right]$, where $A$ is the surface area of the flute $\left[\mathrm{mm}^{2}\right]$;

- proper grinding efficiency: $Q_{w}^{\prime}=Q_{w} / b_{s}\left[\mathrm{~mm}^{3} / \mathrm{mm} \cdot \mathrm{min}\right]$, where: $b_{\mathrm{s}}=a_{\mathrm{p}}$ is the active grinding wheel width [mm].

A rotatable compositional plan was adopted on the star plan for two dependent variables, assuming five levels of values. Parameters were changed in ranges:

- grinding speed $v_{\mathrm{s}}-$ from 15 to $40 \mathrm{~m} / \mathrm{s}$,

- feed speed $v_{f}-$ from 40 to $100 \mathrm{~mm} / \mathrm{min}$.

The test results are summarized in tab. II.

TABLE II. Grinding results and a summary of the research plan

\begin{tabular}{|c|c|c|c|c|c|c|}
\hline Lp. & $\begin{array}{c}V_{f}, \\
\mathrm{~mm} / \mathrm{min}\end{array}$ & $\begin{array}{c}V_{\mathrm{s}}, \\
\mathrm{m} / \mathrm{s}\end{array}$ & $\begin{array}{c}Q_{w}, \\
\mathrm{~mm}^{3} / \mathrm{min}\end{array}$ & $\begin{array}{c}Q_{\mathrm{w}}^{\prime}, \\
\mathrm{mm}^{3} / \mathrm{mm} \cdot \mathrm{min}\end{array}$ & $\begin{array}{c}S a, \\
\mu \mathrm{m}\end{array}$ & $\begin{array}{c}F_{\mathrm{n}}, \\
\mathrm{N}\end{array}$ \\
\hline 1 & 50 & 35 & 612 & 129 & 1.162 & 119 \\
\hline 2 & 40 & 28 & 490 & 103 & 1.203 & 105 \\
\hline 3 & 90 & 20 & 1102 & 231 & 1.142 & 202 \\
\hline 4 & 70 & 40 & 857 & 180 & 1.205 & 170 \\
\hline 5 & 50 & 20 & 612 & 129 & 1.273 & 192 \\
\hline 6 & 90 & 35 & 1102 & 231 & 1.002 & 215 \\
\hline 7 & 70 & 28 & 857 & 180 & 1.037 & 175 \\
\hline 8 & 70 & 28 & 857 & 180 & 1.038 & 170 \\
\hline 9 & 70 & 15 & 857 & 180 & 1.221 & 200 \\
\hline 10 & 100 & 28 & 1224 & 257 & 1.299 & 156 \\
\hline 11 & 40 & 40 & 490 & 103 & 1.122 & 70 \\
\hline 12 & 100 & 40 & 1224 & 257 & 0.981 & 159 \\
\hline
\end{tabular}


On the basis of the obtained results, equations of mathematical models were described, describing the change of the $S a$ roughness parameter and the normal component $F_{\mathrm{n}}$ of the grinding force.

The function of the test object was adopted in the form of a second degree polynomial with two-factor interactions, which is described by the following relationships:

$$
\begin{aligned}
& S a=1.074-0.087 \cdot v_{\mathrm{s}} \cdot v_{\mathrm{f}}+0.047 \cdot v_{\mathrm{s}}^{2}+0.076 \cdot v_{\mathrm{f}}^{2} \\
& F_{\mathrm{n}}=185.662-12.895 \cdot v_{\mathrm{s}}+24.429 \cdot v_{\mathrm{f}}-20.055 \cdot v_{\mathrm{f}} \cdot v_{\mathrm{s}}
\end{aligned}
$$

The coefficients for the model (2) are respectively:

- coefficient of determination $R^{2}=0.8$;

- adjusted coefficient of determination $\bar{R}^{2}=0.731$.

The coefficients for the model (3) are respectively:

- coefficient of determination $R^{2}=0.788$;

- adjusted coefficient of determination $\bar{R}^{2}=0.709$.

The dependence of the parameter of the $S a$ roughness and the normal component $F_{\mathrm{n}}$ of the grinding force on the technological parameters are shown in fig. 4 and fig. 5 .

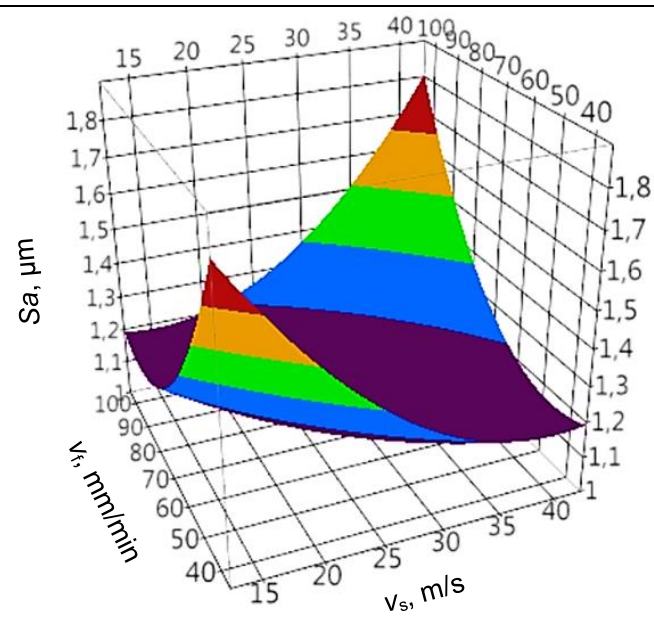

Fig. 4. Influence of grinding speed $v_{s}$ feed velocity $v_{f}$ on the surface roughness parameter of a chipboard groove

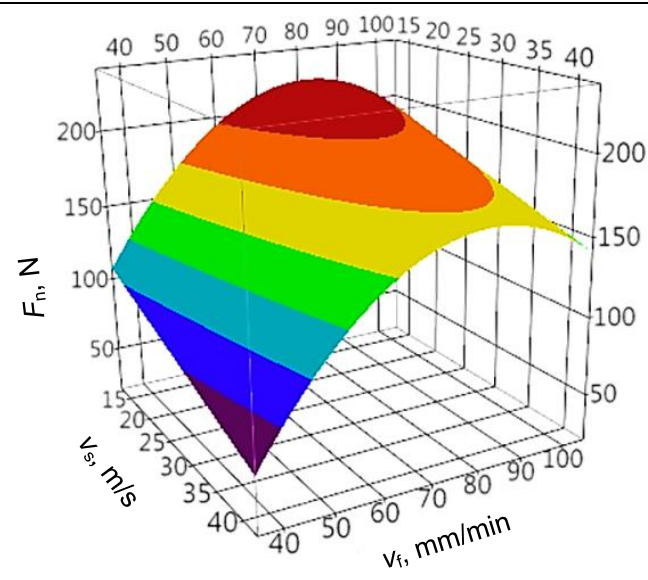

Fig. 5. Influence of grinding speed $v_{s}$ feed speed $v_{f}$ on the norma component $F_{\mathrm{n}}$ grinding force

The $Q_{w}^{\prime}$ grinding efficiency in the carried out tests varied from 103 to $257 \mathrm{~mm}^{3} / \mathrm{mm} \cdot \min$. For trials No. 6 and 12 (tab. II), in which the grinding performance was the highest -231 and $257 \mathrm{~mm} 3 / \mathrm{mm} \cdot \min$, with the speed of grinding $v_{\mathrm{s}}$ equal to 35 and $40 \mathrm{~m} / \mathrm{s}$, so-called grinding burn.

Analyzing the $F_{\mathrm{n}}$ normal component of the grinding force of the flute, it was noted that depending on the experiment carried out it varies in the range up to 70 to $215 \mathrm{~N}$, and the range of the normal component for all tests is as high as
$146 \mathrm{~N}$. The effect is the elastic deformation of the tool and consequently - dimensional errors of the ground tool. For the speed of feed $V_{f}=90 \mathrm{~mm} / \mathrm{min}$ and grinding speed $v_{\mathrm{s}}=35 \mathrm{~m} / \mathrm{s}$, the normal component achieves the highest value of $F_{\mathrm{n}}=215 \mathrm{~N}$ (test No. 6). For the feedrate $v_{\mathrm{f}}=40$ $\mathrm{mm} / \mathrm{min}$ and grinding speed $v_{\mathrm{s}}=40 \mathrm{~m} / \mathrm{s}$, the normal component achieves the smallest value $F_{\mathrm{n}}=70 \mathrm{~N}$ (test No. 11).

From the mathematical model obtained, it results that the feed rate has the greatest effect on the increase in the value of the normal grinding force component.

\section{Conclusions}

Based on the analysis of the surface roughness parameter of the Sa surface, it was found that depending on the technological parameters it varies from 1.03 to $1.3 \mu \mathrm{m}$ (the samples in which the grinding burn occurred), and the parameter value ranges They were $0.27 \mu \mathrm{m}$ for all trials.

It should be mentioned that the chip groove in solid carbide milling cutters is responsible for the chip evacuation process from the machining zone, hence the roughness of the flute surface plays a decisive role. In addition to the roughness parameters, an important factor in assessing the quality of the surface of the flute is the occurrence of defects in the form of scratches or inclusions.

No surface irregularities or irregular inclusions were noticed in any grinding tests.

For the feedrate $v_{f}=100 \mathrm{~mm} / \mathrm{min}$ and grinding speed $v_{\mathrm{s}}=28 \mathrm{~m} / \mathrm{s}$, the Sa parameter achieves the highest value, i.e. $1.3 \mu \mathrm{m}$ (test No. 10).

The smallest value of $S a$, i.e. $1.03 \mu \mathrm{m}$ (sample No. 7), was noted at feed speed $v_{f}=70 \mathrm{~mm} / \mathrm{min}$ and cutting speed $v_{\mathrm{s}}=28 \mathrm{~m} / \mathrm{s}$.

It was found that the technological parameters significantly affect the Sa parameter roughness, but taking into account the range of results, this effect is small.

\section{REFERENCES}

1. Hubert Ch. "Schleifen von Hartmetall-und Vollkeramik Schaftfrasern". Berlin: TU, Diss., 2011.

2. Fujara M. "Methode zur rechnerunterstutzten Auslegung und Optimierung der Geometrie des Vollhartmetall-Spiralbohrers". Darmstadt: Techn. Univ., Diss., 2011.

3. Christoph H. "Schleifen von Hartmetal - und VolkeramikSchaftfasern". Berlin: TU, Diss., 2011.

4. Burek J., Sałata M., Żółkoś M., Żurawski K., Żurek P. „Wpływ kąta pochylenia spirali rowka wiórowego oraz typu ściernicy na jego kształt oraz siłę szlifowania". Mechanik. 8-9 (2017): pp. 772-774.

5. PN-EN ISO 25178-2 Specyfikacje geometrii wyrobów (GPS) Struktura geometryczna powierzchni: przestrzenna - Terminy, definicje i parametry struktury geometrycznej powierzchni.

6. Staniewicz-Brudnik N., Baczek E., Skrabalak G., Wilk W. „Wpływ prędkości szlifowania ściernicami diamentowymi ze spoiwem ceramicznym na jakość powierzchni narzędziowego materiału kompozytowego do obróbki żeliwa". Mechanik. 8-9 (2014): pp. 302-306.

7. Guachao L., Lie S., Jiafeng L. "Modeling and analysis oh helical groove grinding in end mill machining". Journal of Materials Processing Technology. 214, 12 (2014): pp. 3067-3076.

8. Malkin S., Guo C. "Grinding Technology". Industrial Press New York 2008.

Translation of scientific articles, their computer composition and publishing them on the website www.mechanik.media.pl by original articles in Polish is a task financed from the funds of the Ministry of Science and Higher Education designated for dissemination of science.

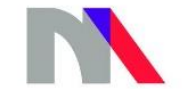

Ministry of Science and Higher Education Republic of Poland 